\title{
A Major Histocompatibility Complex Class I-related Fc Receptor for IgG on Rat Hepatocytes
}

\author{
Richard S. Blumberg, * Tamara Koss, * Craig M. Story, ${ }^{\ddagger}$ Donatella Barisani, * John Polischuk, * Alexander Lipin, * \\ Lourdes Pablo, ${ }^{\ddagger}$ Richard Green, ${ }^{*}$ and Neil E. Simister ${ }^{\ddagger}$ \\ *Gastroenterology Division, Brigham \& Women’s Hospital, Harvard Medical School, Boston, Massachusetts 02115; and ${ }^{\ddagger}$ Rosenstiel \\ Center for Basic Biomedical Sciences and Biology Department, Brandeis University, Waltham, Massachusetts 02254
}

\begin{abstract}
Intestinal epithelial cells of the neonatal rat and mouse have been shown to express a major histocompatibility complex (MHC) class I-like Fc receptor, or FcRn, which transports IgG in an apical to basolateral direction. Previous studies have suggested the possible expression of this receptor beyond the neonatal period within the liver. Since bile contains high levels of IgG, we sought to determine whether the FcRn was functionally expressed by adult rat hepatocytes. Using primers specific for FcRn, which did not cross hybridize with MHC class I transcripts, FcRn DNA was amplified by reverse transcriptase polymerase chain reaction from RNA of adult rat hepatocytes. This RNA contained functional FcRn transcripts as it encoded a $\beta_{2}$-microglobulin-associated cell surface protein as determined by immunoprecipitation of biotinylated cell surface proteins with a polyclonal anti-FcRn specific antiserum. Western blotting of hepatocyte canalicular (apical) and sinusoidal (basolateral) plasma membranes with an FcRn-specific monoclonal antibody further confirmed the protein expression and suggested that FcRn was enriched on the canalicular surface membranes. FcRn, on the surface of hepatocytes, was biologically functional as it bound Fc fragments of IgG at pH 6.0 but not 8.0, which is the same pH dependence observed for FcRn in rat neonatal enterocytes. Thus, FcRn is functionally expressed outside of the neonatal period on the canalicular cell surface of adult hepatocytes. This suggests that hepatocyte FcRn may bind luminal IgG, providing a potential functional communication between parenchymal immune cells and bile. (J. Clin. Invest. 1995. 95:2397-2402.) Key words: bile $\cdot$ liver $\cdot$ immunosurveillance $\cdot$ Kupffer cells - lymphocytes • Fc receptor
\end{abstract}

\section{Introduction}

The transport of immunoglobulin across an epithelial surface for specific immunoprotection of the external epithelial surface

Address correspondence to Richard S. Blumberg, M.D., Gastroenterology Division, Thorn Biomedical Research Building Room 1310, Brigham \& Women's Hospital, 75 Francis Street, Boston, MA 02115. Phone: 617-732-6917; FAX: 617-730-5807.

Received for publication 24 June 1994 and in revised form 9 February 1995.

\section{J. Clin. Invest.}

(c) The American Society for Clinical Investigation, Inc.

0021-9738/95/05/2397/06 \$2.00

Volume 95, May 1995, 2397-2402 may occur by receptor nonspecific and specific mechanisms. Receptor-nonspecific mechanisms, which likely account for the diffusion of IgG into luminal fluids, are typically represented by paracellular sieving events whose efficiency is inversely related to the molecular weight of the transported molecule $(1,2)$. Descriptions of receptor-specific transport are thus far limited to either the polymeric immunoglobulin receptor or a major histocompatibility complex (MHC) class I-related Fc receptor (3-5). These two receptor systems differ in their specificity for immunoglobulin isotype, the vectoral direction of transport, and cell type of expression within the species. The polymeric immunoglobulin receptor is expressed on the basolateral surfaces of enterocytes, hepatocytes, and biliary ductular epithelial cells, and transports polymeric IgA and IgM to the apical surfaces, concentrating these immunoglobulins for antimicrobial defense and antigen exclusion (3). The enterocyte receptor for IgG, which has homology to the MHC class I heavy chain and is associated with $\beta_{2}$-microglobulin $\left(\beta_{2} \mathbf{M}\right),{ }^{1}$ is expressed on neonatal enterocytes of the rat and mouse $(4,5)$. IgG is transported transcellularly in a luminal to serosal direction across the intestinal epithelium of the neonate $(6,7)$. The neonatal Fc receptor $(\mathrm{FcRn})$ is likely to be responsible for passive loading of the neonate with maternally derived antibodies and/or antibody/antigen complexes (6-8). Both may play a role in molding the immature immune system. On the apical surface of the enterocyte, the Fc portion of IgG is bound at the relatively acidic $\mathrm{pH}$ of the lumen. After transcytosis to the basolateral plasma membrane, discharge of the immunoglobulin occurs at the neutral $\mathrm{pH}$ of the interstitial fluids $(6,7)$.

In this report, we show that the MHC class I-related FcRn of the rat is also functionally expressed on the surface of adult rat hepatocytes. The further observation that $F c R n$ is present on the canalicular membranes of hepatocytes places this molecule in an anamic context which allows for interactions with biliary IgG and immune complexes. These data have important implications for the presumed function of $\mathrm{FcRn}$, for the role of the high concentrations of IgG previously observed in biliary fluids, and for immunosurveillance of the epithelial surfaces in general.

\section{Methods}

Antibodies. The rabbit anti-rat antibody for the FcRn is a polyclonal antiserum specific for the FcRn heavy chain (4). Normal rabbit serum

1. Abbreviations used in this paper: $\beta_{2} \mathrm{M}, \beta_{2}$-microglobulin; ECL, enhanced chemiluminescence; FcRn, neonatal enterocyte Fc receptor; ISBC, immunoglobulin-secreting B cell; RT, reverse transcriptase. 
(Sigma Chemical Co., St. Louis, MO) served as the negative control. 1G3 is a mouse anti-rat FcRn monoclonal antibody (kindly provided by M. Raghavan, California Institute of Technology, Pasadena, CA) (9).

Rat hepatocytes. Rat hepatocytes were prepared from normal, $250 \mathrm{~g}$, Sprague-Dawley rats and resuspended in William's E media as described previously $(10,11)$. A Percoll gradient centrifugation was done which has been shown to give $>99 \%$ pure hepatocyte preparations (12). This was confirmed using esterase staining which identifies Kupffer cells.

Cell lines. LRP-1 (kindly provided by Dr. Joan S. Hunt, University of Kansas Medical Center, Kansas City, KS ) is a rat trophoblast-derived cell line.

Reverse transcriptase ( $R T)-P C R$. The cDNA Cycle Kit (Invitrogen, San Diego, CA) was used to prepare first strand cDNA for PCR. Total RNA ( $1 \mu \mathrm{g})$ from either rat neonatal intestine or adult rat hepatocytes was used as a template. Two 1-h rounds of cDNA synthesis were done at $42^{\circ} \mathrm{C}$ using random primers. PCR was done on phenol/chloroformextracted and ethanol-precipitated cDNA using Taq polymerase (PerkinElmer Cetus, Norwalk, CT) and the cycle conditions: $30 \times\left(94^{\circ} \mathrm{C}, 1\right.$ $\min ; 55^{\circ} \mathrm{C}, 2 \mathrm{~min} ; 72^{\circ} \mathrm{C}, 3 \mathrm{~min}$ ). The amplification primers used, shown $5^{\prime}$ to $3^{\prime}$, were: TGCGGTTCAACCCAAGAA ( $\alpha 2$ domain of FcRn, primer D), and TCATCTCCACGTTTGACC ( $\alpha 3$ domain of FcRn, primer E). PCR products were resolved by electrophoresis on a $1.5 \%$ agarose gel, stained with ethidium bromide, and photographed. The 388bp D to E product was excised from a $1.5 \%$ gel and electrophoretically transferred to low melting agarose (NuSieve ${ }^{\circledR}$ GTG $^{\circledR}$; FMC Corp. Bioproducts, Rockland, ME). Thermal cycle sequencing (CircumVent Kit; New England Biolabs Inc., Beverly, MA) was performed directly on DNA from the agarose, using ${ }^{32} \mathrm{P}$ end-labeled primers $\mathrm{D}$ and $\mathrm{E}$.

Northern blot. Total RNA (10 $\mu \mathrm{g})$ was resolved on a denaturing agarose gel and transferred to a nylon membrane (Biotrans ; ICN, Irvine, CA). RNA was cross-linked to the membrane by ultraviolet illumination (Stratalinker ${ }^{\circledR}$; Stratagene, La Jolla, CA). The blot was hybridized with $2 \times 10^{6} \mathrm{cpm} / \mathrm{ml}$ of ${ }^{32} \mathrm{P}$-labeled probe made by a random primer method (Prime-it ${ }^{\circledR m T}$; Stratagene) and passed through a 1$\mathrm{ml} \mathrm{G} 25$ spin column to remove free nucleotides. The blot was hybridized for $1 \mathrm{~h}$ in Quickhyb ${ }^{\Lambda}$ (Stratagene) at $68^{\circ} \mathrm{C}$; the final wash was 0.1 $\times$ SDS at $60^{\circ} \mathrm{C}$. The blot was exposed on a phosphor screen (Eastman Kodak Co., Rochester, NY) and analyzed on a PhosphorImager (Molecular Dynamics, Sunnyvale, CA).

Preparation of basolateral and canalicular rat hepatocyte plasma membranes. Canalicular and basolateral plasma membranes were isolated using a modification of the method of Song et al. (13). Briefly, after an overnight fast, the animals were killed, the liver was excised,

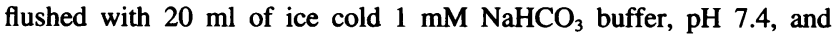
homogenized with 15 strokes of a Dounce homogenizer in $\mathrm{NaHCO}_{3}$ buffer. After filtering through gauze, a sample of the homogenate was collected and the remaining homogenate was centrifuged for $10 \mathrm{~min}$ at $1,500 \mathrm{~g}$. The pellet was resuspended in $5.5 \mathrm{vol}$ of $56 \%(\mathrm{wt} / \mathrm{wt}$ ) sucrose solution, and a discontinuous sucrose gradient (with 42 and $38 \%$ wt/ wt sucrose) was layered. The membranes were centrifuged for $60 \mathrm{~min}$ at $66,000 \mathrm{~g}$. The upper interface (canalicular fraction) was removed, washed in $\mathrm{NaHCO}_{3}$ buffer, and repelleted at $1,500 \mathrm{~g}$. The lower interface was resuspended in sucrose to a density of $1.22(\mathrm{~g} / \mathrm{ml})$, and the discontinuous sucrose gradient and centrifugation steps were repeated. The lower interface (basolateral fraction) was removed, washed with $1 \mathrm{~mm}$ $\mathrm{NaHCO}_{3}$, and repelleted. Membranes were resuspended in $250 \mathrm{mM}$ sucrose, $10 \mathrm{mM}$ Hepes, $\mathrm{pH} 7.4$, solution. All procedures were performed at $4^{\circ} \mathrm{C}$. Membrane protein concentrations were quantitated using the Bradford method of protein quantification (Biorad, Hercules, CA) with BSA as a standard. Membrane purity was validated using the characteristic enzyme markers $\mathrm{Na}^{+}-\mathrm{K}^{+}$ATPase (sinusoidal), NADPH cytochrome $c$ reductase (endoplasmic reticulum), and leucine aminopeptidase (canalicular), and measuring for enrichment and/or exclusion of enzymatic activity relative to the homogenate as described previously (14).

Cell surface biotinylation and immunoprecipitation. Approximately $3 \times 10^{7}$ rat hepatocytes were washed four times with ice cold HBSS containing no calcium or magnesium (HBSS - ). The hepatocytes were then incubated for two 20 -min periods with $1.5 \mathrm{ml}$ sulpho-NHS biotin (Pierce, Rockford, IL) diluted to $0.5 \mathrm{mg} / \mathrm{ml}$ in DMSO. After labeling, the hepatocytes were washed five times with $50 \mathrm{mM} \mathrm{NH}_{4} \mathrm{Cl}$, incubated for 20 min with $10 \mathrm{ml}$ of RPMI 1640 medium (Cellgro) containing 1 mM L-glutamine (Mediatech, Inc., Herndon, VA), and washed four times with HBSS-. The labeled cells were lysed on ice with $1 \mathrm{ml}$ of immunoprecipitation buffer containing $20 \mathrm{mM}$ Tris, $\mathrm{pH} 8.0,150 \mathrm{mM}$ $\mathrm{NaCl}, 1 \mathrm{mM}$ EDTA, $10 \mathrm{mM}$ iodoacetamide, $1 \%$ Nonidet P-40, $200 \mu \mathrm{g} /$ ml BSA, phenylmethylsulphonylfluoride (PMSF) $(100 \mu \mathrm{g} / \mathrm{ml})$, and aprotinin, chymostatin, pepstatin A, antipain, and leupeptin (each $1 \mu \mathrm{g} /$ $\mathrm{ml}$ ). After $30 \mathrm{~min}$ on ice, the lysate was centrifuged at $14,000 \mathrm{~g}$ for 15 $\min$ at $4^{\circ} \mathrm{C}$. The supernatant was centrifuged for $30 \mathrm{~min}$ at $4^{\circ} \mathrm{C}$ at 100,000 $g$ in a TL-100 ultracentrifuge (Beckman Instruments, Inc., Fullerton, CA). The supernatant was collected and precleared overnight at $4^{\circ} \mathrm{C}$ with $20 \mu \mathrm{l}$ of packed protein A-Sepharose beads (Pharmacia LKB Biotechnology Inc., Piscataway, NJ). Before immunoprecipitation, SDS and desoxycholic acid were added to final concentrations of 0.1 and $0.5 \%$, respectively. After heating for $5 \mathrm{~min}$ at $95^{\circ} \mathrm{C}$, the lysate was precleared three times with normal rabbit serum and immunoprecipitated with the rabbit anti-rat $\mathrm{Fc}$ receptor antibody as described previously (15). The immunoprecipitates were then washed 10 times with immunoprecipitation buffer and resuspended in $30 \mu \mathrm{l}$ of Laemmli sample buffer (16) containing no reducing agents.

PAGE and Western blotting using enhanced chemiluminescence $(E C L)$. The immunoprecipitates were resolved by PAGE in the presence of SDS and transferred to nitrocellulose as described previously (15). The nitrocellulose was blocked three times for $20 \mathrm{~min}$ each in a buffer containing $0.15 \mathrm{M} \mathrm{NaCl}, 5 \mathrm{mM}$ EDTA, $50 \mathrm{mM}$ Tris, pH 7.5, $0.05 \%$ Triton X-100, $200 \mu \mathrm{g} / \mathrm{ml} \mathrm{BSA}$, and $0.25 \%$ gelatin, and then incubated for $1 \mathrm{~h}$ at room temperature in streptavidin-horseradish peroxidase (Pierce) at a dilution of 1:10,000 in the blocking buffer. Subsequently, the nitrocellulose membrane was washed as follows: $5 \mathrm{~min}$ in $0.05 \mathrm{M}$

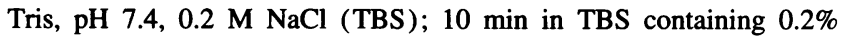
Tween 20; $10 \mathrm{~min}$ in TBS; $10 \mathrm{~min}$ in $0.1 \mathrm{M}$ Tris, $\mathrm{pH} 7.4,0.5 \mathrm{M} \mathrm{NaCl}$; $10 \mathrm{~min}$ in TBS; $10 \mathrm{~min}$ in TBS containing $0.05 \%$ SDS; $10 \mathrm{~min}$ in TBS containing $0.2 \%$ Tween 20 ; and $10 \mathrm{~min}$ in TBS. The nitrocellulose was then placed in the ECL solution (Amersham Life Science, Buckinghamshire, United Kingdom) and exposed on x-ray film.

Plasma membrane vesicles containing $100 \mu \mathrm{g}$ of protein were solubilized directly in Laemmli sample buffer containing reducing agents and $100 \mu \mathrm{g} / \mathrm{ml}$ PMSF. The solubilized proteins were resolved by SDSPAGE and immunoblotted as described previously (15) with the FcRn heavy chain-specific monoclonal antibody, 1G3, as ascites diluted 1:250 in phosphate-buffered saline containing 5\% nonfat dry milk (Carnation) and $0.02 \%$ sodium azide. Detection was accomplished with a goat anti-mouse horseradish peroxidase-conjugated antibody and ECL as described above.

Fc binding assay. Rat hepatocytes were dispensed into microcentrifuge tubes $\left(2 \times 10^{6}\right.$ cells/tube $)$ and spun down at $2,000 \mathrm{rpm}$ for 2-3 $\mathrm{min}$ at $4^{\circ} \mathrm{C}$. The resulting cell pellets were washed with DME, $20 \mathrm{mM}$ Hepes, pH 6.0 or 8.0 , at $4^{\circ} \mathrm{C}$, and resuspended in $0.2 \mathrm{ml}$ of the same medium. The cell suspension was then seeded into 12 -well plates and assayed immediately. ${ }^{125} \mathrm{I}-\mathrm{Fc}\left(200 \mathrm{ng} \mathrm{ml}^{-1}, 4 \times 10^{-9} \mathrm{M}\right)$ in DME, 20 $\mathrm{mM}$ Hepes, $1 \mathrm{mM} \mathrm{KI}, 0.1 \%$ fish gelatin, $\mathrm{pH} 6.0$ or 8.0 , with or without $0.5 \mathrm{mg} \mathrm{ml}^{-1}$ unlabeled human IgG $\left(3.3 \times 10^{-6} \mathrm{M}\right)$ was added to each well. Cells were allowed to bind $\mathrm{IgG}$ at $37^{\circ} \mathrm{C}, 5 \% \mathrm{CO}_{2}$ for $2 \mathrm{~h}$. Cells were then transferred to microcentrifuge tubes and spun down at 2,000 rpm for 2-3 $\mathrm{min}$ at $4^{\circ} \mathrm{C}$. Unbound ligand was removed by washing the pellets once with DME, $20 \mathrm{mM}$ Hepes, $\mathrm{pH} 6.0$ or 8.0 , at $4^{\circ} \mathrm{C}$. Cells were then spun down, dissolved in $0.5 \mathrm{ml} 0.1 \mathrm{M} \mathrm{NaOH}$, and transferred to vials. The bound radioligand was measured in a CliniGamma 1272 gamma counter (LKB Wallace, Piscataway, NJ).

\section{Results}

Expression of FcRn message by adult rat hepatocytes. Previous studies on the tissue distribution of the FcRn in the rat by 
a

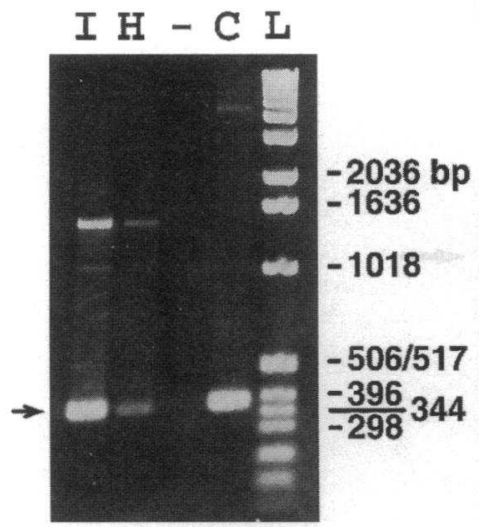

b

tgcggttcaacccaagaaCGGGCAACTGGAGTGCGGAGTGCCCGGAGACA GATATCGNGGTAATCTGTGGATGAAGCAACCTGAGGCGGCCAGGAAGGA GAGCGAGNTCCTGCTAACTTCTTGTCCTGAGCGGCTGCTAGGCCACCTGG AGAgGGGCCGTCAGAACCTGGagTGGaAgGagCCGCCATCTATECGCCTO AAGGCCCGTCCTGGCAACTCTGGCTCCTCAGTACTGACCTGTGCTGCTTT CTCCTTCTACCCGCCGGAGCTCAAGTITCGATICCTGCGCAATGGGCTAG CCTCAGGCTCTGGGAATTGCAGCACTGGTCOCAATGGTGATGGATCTTPC CATGCATGGTCATTGCTAGAggtcaaacgtggagatga
Figure 1. PCR amplification of FcRn mRNA. (a) Products of RT-PCR on RNA from adult rat hepatocytes and neonatal rat intestine. Lanes are: intestine, $I$; hepatocytes, $H$; blank, -; cDNA positive control, $C$; 1 -kb Ladder, $L$. Since amplification primers were used which amplify across the $\alpha 2 / \alpha 3$ exon boundary, the second band seen for both tissues at $\approx 1.5 \mathrm{~kb}$ is probably derived from contaminating genomic DNA. The specific product of $388 \mathrm{bp}$ is indicated by an arrow. ( $b$ ) Partial sequence of the 388-bp band amplified from hepatocyte RNA. The nucleotide sequence of the predicted 388-bp fragment is shown with the location of the $\mathrm{D}$ and $\mathrm{E}$ primers indicated by lowercase letters. Sequence readable on the gel autoradiogram is underlined and is identical with the previously published rat FcRn sequence (GenBank M35495).
Northern blotting showed evidence of possible FcRn transcription in adult rat liver (4). Since the transcript was only identified at long exposures with near full-length cDNA probes, it could not be determined whether the minor transcripts observed represented cross hybridization with MHC class I transcripts. To readdress whether a specific message for the FcRn could be identified in adult rat liver, RT reactions were done on rat hepatocyte RNA, followed by PCR with primers specific for the rat FcRn. PCR products from the primer pair D and E are shown in Fig. $1 a$, where the expected band of $388 \mathrm{bp}$ is clearly seen. To determine whether the product in the hepatocyte lane was indeed amplified FcRn, this band was excised and directly sequenced. The portion of the PCR fragment sequenced, underlined in Fig. $1 b$, was $100 \%$ identical to the previously determined sequence of rat $\mathrm{FcRn}$ and did not contain any intron sequences indicating their origin from mRNA and not genomic DNA. Confirmation of the authenticity and relative quantity of the FcRn mRNA detected was obtained by Northern blotting. Using the full-length FcRn as a probe, a specific message of $\sim 1.7 \mathrm{~kb}$ (arrow) could be detected in rat neonatal jejunum and adult hepatocytes but not the rat trophoblast-derived cell line, LRP-1 (Fig. 2). The quantity of specific message detected in the adult rat hepatocytes was lower than the levels detected in rat neonatal jejunum, further suggesting that transcriptional levels of FcRn may be regulated either developmentally or in an organ-specific fashion.

Expression of FcRn on the cell surface of rat hepatocytes. To determine whether the observed FcRn message encoded detectable protein, immunoprecipitation of cell surface proteins was performed. Total cell surface proteins of normal adult rat hepatocytes were biotinylated and a lysate of biotinylated proteins was prepared in immunoprecipitation buffer containing $\mathrm{NP}-40$, at $\mathrm{pH} 8.0$, to prevent binding of the Fc region of immunoglobulin by the FcRn $(6,7)$. Resolution of the immunoprecipitates using normal rabbit serum, as a control, and an antiFcRn heavy chain-specific antiserum is shown under nonreducing conditions in Fig. 3. Note, with the FcRn heavy chainspecific antibody (lane 2), the presence of a smear between 48 and $54 \mathrm{kD}$ (arrow), the approximate size of the FcRn heavy chain, and a band of $12 \mathrm{kD}$ (open arrow), the size of the $\beta_{2} \mathrm{M}$ light chain. Low amounts of several bands between 50 and $52 \mathrm{kD}$ were observed with the normal rabbit serum (lane 1 ).

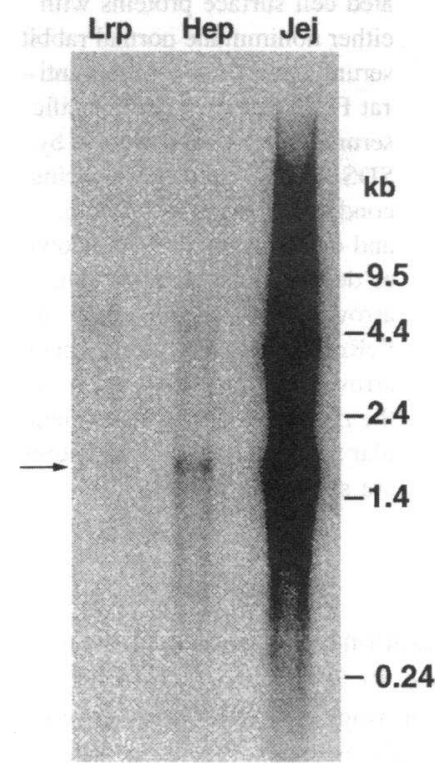

Figure 2. Northern blot of FcRn mRNA. Northern blot of total cellular RNA $(10 \mu \mathrm{g})$ from rat trophoblast-derived cell line LRP-1 ( $L r p$ ), rat hepatocytes (Hep), and neonatal rat jejunum $(\mathrm{Jej})$. Northern blot was probed with full-length FcRn. A second, shorter probe, consisting of rat FcRn $\alpha 1$ sequence only, gave indistinguishable results for these RNAs on other blots (data not shown). Loading of lanes was approximately equal as judged by ethidium bromide staining of ribosomal RNAs. Arrow indicates location of specific, $1.7-\mathrm{kb}$ message in Hep and Jej lanes.

Although it cannot be ruled out that these bands represent some binding of the normal rabbit immunoglobulin by FcRn on hepatocytes despite the stringency of the immunoprecipitation conferred by the $\mathrm{pH}$ of 8.0 and boiling in SDS and desoxycholic acid, this seems unlikely due to the reproducible absence of associated $\beta_{2} \mathrm{M}$ on overexposed images (data not shown). Thus, a FcRn heavy chain-specific antiserum could immunoprecipitate a $\beta_{2} \mathrm{M}$-associated heavy chain from the cell surface of normal adult rat hepatocytes.

Expression of the FcRn on rat hepatocyte cell surface membranes. To further confirm that the FcRn was expressed on the hepatocyte cell surface and to determine its relative expression on the sinusoidal (basolateral) and canalicular (apical) membrane domains, the following studies were performed. Canalicular and sinusoidal plasma membranes were isolated using sucrose gradient centrifugation (13). Sinusoidal and canalicular membrane vesicles were enriched relative to crude liver homogenate 16.8- and 2.6-fold in the specific activity of $\mathrm{Na}^{+}-\mathrm{K}^{+}$ ATPase, respectively, and, 3.42- and 11.8-fold in leucine aminopeptidase activity, respectively. These same sinusoidal and can- 


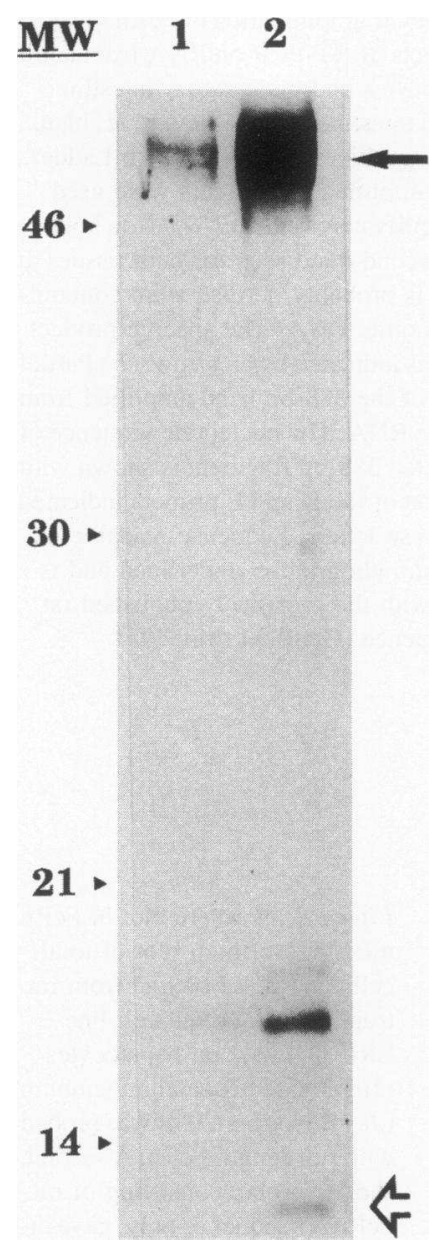

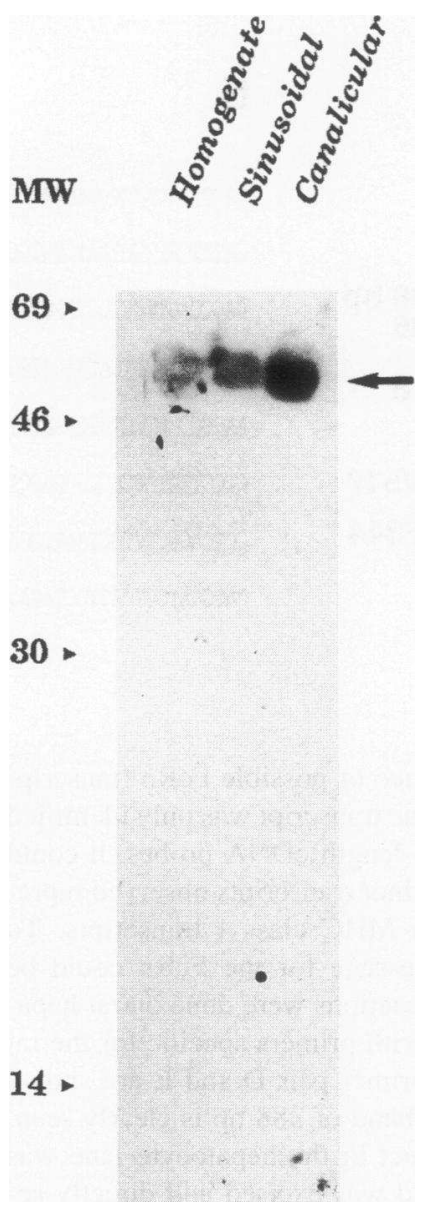

Figure 3. Biochemical detection of FcRn on rat hepatocytes. Immunoprecipitation of biotinylated cell surface proteins with either nonimmune normal rabbit serum (lane 1) or a rabbit antirat FcRn heavy chain-specific serum (lane 2). Resolution by SDS-PAGE under nonreducing conditions, Western blotting, and detection by ECL is shown as described in Methods. The arrow indicates the location of FcRn heavy chain and the open arrow indicates the location of the $\beta_{2} \mathrm{M}$ light chain. The molecular mass markers in kilodaltons are shown on the left.

alicular plasma membrane preparations exhibited exclusion of NADPH-cytochrome $C$-reductase to 0.42 - and 0.53 -fold, respectively, compared with liver homogenate. The homogenate, sinusoidal, and canalicular membrane preparations were solubilized directly in Laemmli buffer with reducing agents. An equivalent amount $(100 \mu \mathrm{g})$ of the solubilized membranes was then resolved by SDS-PAGE and Western blotted with the mouse anti-rat FcRn-specific monoclonal antibody, 1G3. As can be seen in Fig. 4, the FcRn-specific monoclonal antibody detected a band of $\sim 50 \mathrm{kD}$ (arrow), in the homogenate, sinusoidal, and canalicular preparations. This band had the same mobility as the FcRn detected in Fig. 3 with the rabbit anti-rat FcRn antibody. The relative quantity of FcRn detected by this method was greater in the enriched canalicular preparations in comparison with either the homogenate or enriched sinusoidal preparations. This suggests that FcRn expression is enhanced on the apical cell surface of normal adult rat hepatocytes.

Functional expression of FcRn on rat hepatocytes. To determine whether the FcRn on rat hepatocytes was functional and thus competent to bind the $\mathrm{Fc}$ region of IgG, the following studies were performed. Freshly isolated normal rat hepatocytes were incubated at $37^{\circ} \mathrm{C}$ with ${ }^{125} \mathrm{I}$-labeled $\mathrm{IgG} \mathrm{Fc}$ fragments. Binding was defined by determining the quantity of radioactive label bound at either pH 6.0 or 8.0. Fig. 5 shows that normal rat adult hepatocytes bind IgG Fc fragments at $\mathrm{pH} 6.0$, but not at $\mathrm{pH} 8.0$, consistent with the previously described $\mathrm{pH}$ depen-

dence of the FcRn in rat neonatal enterocytes $(6,7)$. Thus, the rat hepatocyte FcRn is functionally competent to bind IgG.

\section{Discussion}

We have shown that FcRn is functionally expressed on the cell surface of normal adult rat hepatocytes. Furthermore, the studies with the plasma membrane preparations suggest that FcRn expression is enhanced on the canalicular (apical) domain of the cell. These data are consistent with earlier observations by Hopf

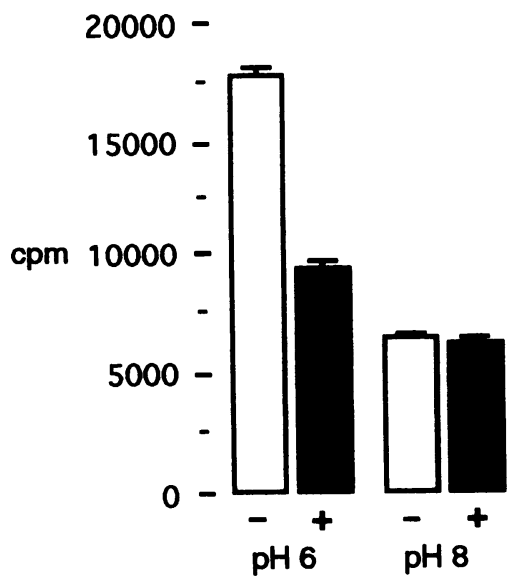

Figure 5. Fc binding by rat hepatocytes. Binding of ${ }^{125} \mathrm{I}-\mathrm{Fc}$ of IgG by freshly isolated adult rat hepatocytes. Assays were done at $37^{\circ} \mathrm{C}$ with (filled columns) and without (open columns) competing unlabeled IgG, at pH 6.0 or 8.0 . Each column represents the mean cell-associated radioactivity in six replicates; bars show the standard error. 


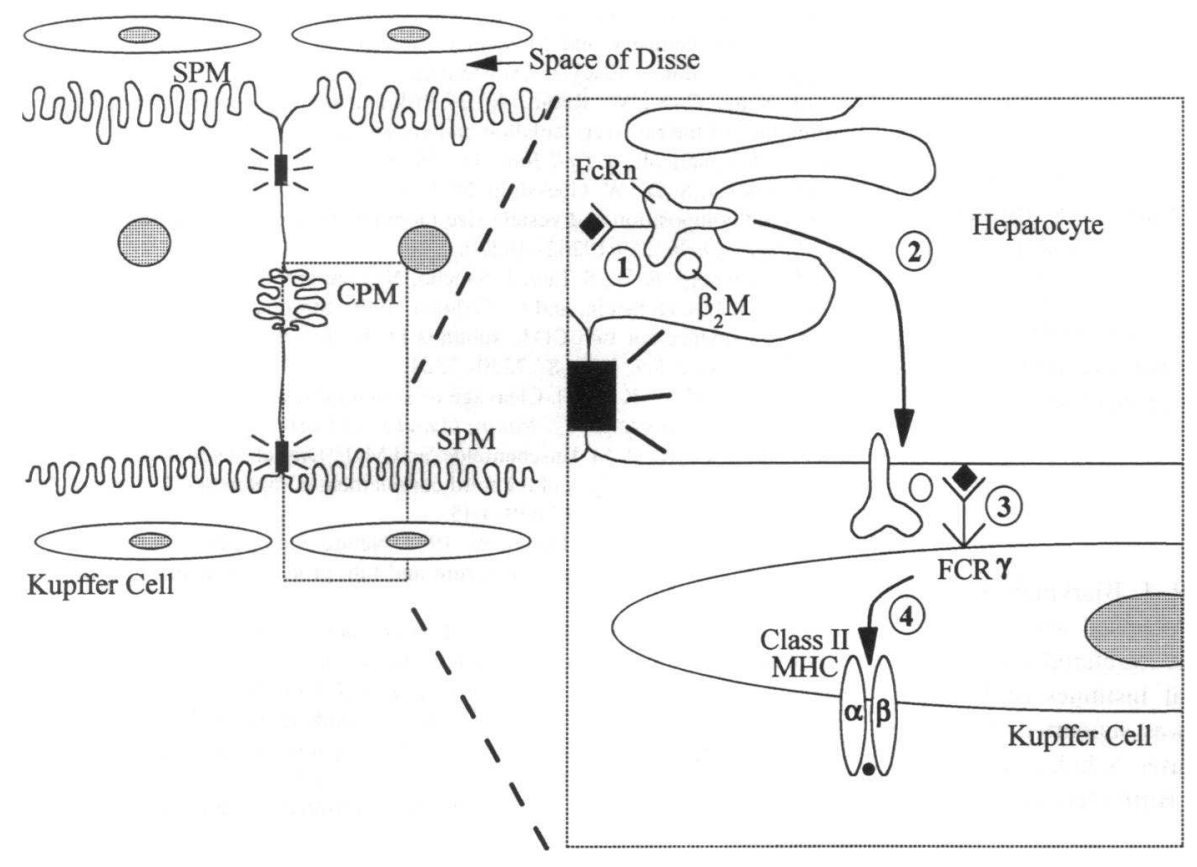

Figure 6. Model of rat hepatocyte FcRn function. (1) The FcRn, predominantly expressed on the canalicular (or apical) plasma membrane $(C P M)$, is an $\sim 51-\mathrm{kD}$ heavy chain noncovalently associated with the $12-\mathrm{kD}$ $\beta_{2} \mathrm{M}$ light chain. The FcRn binds IgG (Y)/ antigen $(\diamond)$ complexes present within the lumen of the canalicular space; (2) The $\mathrm{FcRn} / \mathrm{IgG}$ /antigen complex is delivered to the sinusoidal (basolateral) plasma membrane (SPM); (3) At the relatively neutral $\mathrm{pH}$ of the interstitium within the space of Disse, the IgG/antigen complex dissociates making it available for binding to $\mathrm{Fc} \gamma$ receptors $(\mathbf{V})$ on sinusoidal lining cells, such as Kupffer cells; (4) Via Fc receptor-mediated endocytosis, the IgG/antigen complex is internalized for processing to antigenic peptide $(\bullet)$ and presentation on the cell surface of the sinusoidal lining cell in the context of a MHC class II molecule for presentation to MHC class II-restricted, antigen-specific $\mathrm{CD}^{+} \mathrm{T}$ cells within the hepatic lobule. These would provide the necessary helper factors for local antigen-specific ISBCs.

(17) suggesting that there are IgG Fc binding sites on rabbit hepatocytes. In addition, this expression outside the neonatal period in an anatomic context that would allow interaction with luminal IgG in biliary fluids may provide important insights into the role of $\mathrm{IgG}$ in the biliary tree and its relationship with lymphoid cells within the hepatic parenchyma.

It is well recognized in several species that $\mathrm{IgG}$ is one of the major fractions of protein that is normally present in biliary luminal fluids $(1,18,19)$. IgG concentrations are commonly equivalent to those of $\operatorname{IgA}$ which is concentrated in biliary fluids relative to peripheral blood by the function of the polymeric immunoglobulin receptor $(3,20)$. The origin of the luminal IgG is not completely known and its role in luminal defense is not well appreciated. It is increasingly evident that, to a large extent, luminal IgG is generated by local immunoglobulin-secreting B cells (ISBC) within the hepatic parenchyma (21). These ISBCs increase in number after either enteral or parenteral immunization with a variety of antigens (21-24). In addition, subsequent to immunization, antigen-specific immunoglobulin responses can be observed within the biliary fluids suggesting that local production of IgG leads to luminal diffusion, possibly via paracellular sieving events as described previously in model systems $(21,22)$. Biliary IgG normally possesses specific antibacterial activity in the absence of specific immunization suggesting ongoing production of IgG against a variety of potential luminal pathogenic events $(20,25)$. Indeed, the biliary tract is a site for primary and secondary pathogenic events suggesting that luminal IgG may provide immunoprotection to the biliary tract and upper small intestine. Primary pathogenic events include a variety of parasitic infections whose life cycles may be solely luminal without a phase of tissue invasion (26). During biliary tract obstruction, the biliary tree is commonly secondarily infected with enteric bacteria (27). Thus, the normal and compromised biliary tract is subject to a variety of infectious assaults.

Although the characterization of the enriched plasma membrane preparations clearly documents that the FcRn can be de- tected and may be enriched apically (Fig. 4), as a steady state measurement, these studies do not address the dynamics of receptor movement between the apical (canalicular) and basolateral (sinusoidal) surfaces. One potential model is that the FcRn is responsible for the transport of IgG into bile from blood - a basolateral to apical pathway of receptor movement. Alternatively, akin to the previously described transcytotic pathway in neonatal enterocytes $(6,8)$, the FcRn could provide a mechanism for the transcytosis of IgG and/or IgG/antigen complexes from the apical to the basolateral surface of the hepatocyte. Thus, by virtue of the luminal placement of the FcRn on the canalicular surface, the host might possess the ability to specifically sample for pathogenic luminal antigenic events. In this latter model (Fig. 6), at the relatively neutral $\mathrm{pH}$ of the interstitial tissues within the space of Disse, these antibody/antigen complexes could be discharged and thus available for binding to the Fc receptors of Kupffer cells. Kupffer cells possess functional Fc receptors and are capable of processing and presenting foreign antigenic events via a class II MHC pathway for interaction with $\mathrm{T}$ cells in an antigen-specific and MHC-restricted fashion (28-32). Furthermore, CD4 ${ }^{+} \mathrm{T}$ cells can be observed within the liver $(21,23)$. It is thus feasible that the processing and presentation of luminally derived antigenic peptides by Kupffer cells would lead to the specific activation of antigen-specific, MHC-restricted local T cells and consequently local B cells of the appropriate specificity. These B and $\mathrm{T}$ cells have presumably localized to the hepatic parenchyma consequent to previous extrahepatic enteral, and possibly parenteral, foreign antigen exposures (21-24). In this manner, transcytosis of antibody/antigen complexes by a functional FcRn would provide local immunosurveillance against luminal pathogenic assaults. This is consistent with the immunization data suggesting that enteral immunization leads to the migration of specific ISBCs into hepatic lobules that would be available to monitor biliary luminal events (21). Of interest, prior immunization of rats with irradiated, and thus nonproliferative, forms of the entirely biliary luminal pathogen, Hymenolepsis micros- 
toma, confers resistance to the biliary invasion of live $H$. microstoma parasites administered at a later time (33).

Taken together, these data and proposed model of FcRn function within the rat biliary tract suggest that $\mathrm{FcRn}$ may possess important immunosurveillance functions beyond the neonatal period. Furthermore, these observations may have important implications for epithelial immunity in general if the FcRn or homologous molecules in other species are observed on other adult epithelial surfaces. These hypotheses are readily testable and have important functional implications for mucosal immunoregulation and programs of immunization relevant to the development of mucosal defense.

\section{Acknowledgments}

The authors wish to thank M. Raghavan and P. J. Bjorkman for the $1 G 3$ monoclonal antibody, Elise Pelletier for technical assistance, J. Gollan for helpful advice, and Janet Fox for expert secretarial assistance.

R. S. Blumberg was supported by National Institutes of Health (NIH) grant R01 DK-443189. N. E. Simister was supported by NIH grant R01 HD27691 and Basil O'Connor Starter Scholar Research Award 5-FY92-1040 from the March of Dimes Birth Defects Foundation.

\section{References}

1. Manning, R. J., P. G. Walker, L. Carter, P. J. Barrington, and G. D. F Jackson. 1984. Studies in the origins of biliary immunoglobulins in rats. Gastroenterology. 87:173-179.

2. Mullock, B. M., L. J. Shaw, B. Fitzharris, J. Peppard, M. J. R. Hamilton, M. T. Simpson, T. M. Hunt, and R. H. Hinton. 1985. Sources of proteins in human bile. Gut. 26:500-509.

3. Underdown, B. J., and J. M. Schiff. 1986. Immunoglobulin A: strategic defense initiative at the mucosal surface. Annu. Rev. Immunol. 4:389-417.

4. Simister, N. E., and K. E. Mostov. 1989. An Fc receptor structurally related to MHC class I antigens. Nature (Lond.). 337:184-187.

5. Ahouse, J. J., C. L. Hagerman, P. Mittal, D. J. Gilbert, N. G. Copeland, N. A. Jenkins, and N. E. Simister. 1993. Mouse MHC class I-like receptor encoded outside the MHC. J. Immunol. 151:6076-6088.

6. Jakoi, E. R., J. Cambier, and S. Saslow. 1985. Transepithelial transport of maternal antibody: purification of IgG receptor from newborn rat intestine. $J$. Immunol. 135:3360-3364.

7. Simister, N. E., and A. R. Rees. 1985. Isolation and characterization of an Fc receptor from neonatal rat small intestine. Eur. J. Immunol. 15:733-738.

8. Abrahamson, D. R., A. Powers, and R. Rodewald. 1979. Intestinal absorption of immune complexes by neonatal rats: a route of antigen transfer from mother to young. Science (Wash. DC). 206:567-569.

9. Raghavan, M., M. Y. Chen, L. N. Gastinel, and P. J. Bjorkman. 1994 Investigation of the interaction between the class I MHC-related Fc receptor and its immunoglobulin G ligand. Immunity. 1:393:351-358.

10. Burke, S., S. Landau, R. Green, C. C. Tseng, T. Nattakom, W. Canchis, L. Yang, D. Kaiserlian, C. Gespach, S. Balk, and R. Blumberg. 1994. Rat cluster of differentiation 1 molecule: expression on the surface of intestinal epithelial cells and hepatocytes. Gastroenterology. 106:1143-1149.

11. Green, R. M., J. F. Whiting, A. B. Rosenbluth, D. Beier, and J. L. Gollan. 1994. Interleukin-6 inhibits hepatocyte taurocholate uptake and sodium-potassium-adenosinetriphosphatase activity. Am. J. Physiol. 267:G1094-G1100.

12. Berry, M. N., A. M. Edwards, and G. J. Barritt. 1991. Hepatocyte isolation for primary culture and methods for non-adherent culture. In Laboratory Techniques in Biochemistry and Molecular Biology. R. H. Burdon and P. H. van Knippenberg, editors. Elsevier, Amsterdam. 237-263.

13. Song, C. S., W. Rubin, A. B. Rifkind, and A. Kappas. 1969. Plasma membranes of the rat liver: isolation and enzymatic characterization of a fraction rich in bile canaliculi. J. Cell Biol. 41:124-132.

14. Zucker, S. D., W. Goessling, M. L. Zeidel, and J. L. Gollan. 1994. Membrane lipid composition and vesicle size modulate bilirubin intermembrane transfer. J. Biol. Chem. 269:19262-19270.

15. Blumberg, R. S., S. Ley, J. Sancho, N. Lonberg, E. Lacy, F. McDermott, V. Schad, J. L. Greenstein, and C. Terhorst. 1990. Structure of the T-cell antigen receptor: evidence for two $\mathrm{CD} 3 \epsilon$ subunits in the T-cell receptor-CD3 complex. Proc. Natl. Acad. Sci. USA. 87:7220-7224.

16. Laemmli, U. K. 1970. Cleavage of structural proteins during assembly of the head of bacteriophage $\mathrm{T}_{4}$. Nature (Lond.). 227:680-685.

17. Hopf, U., K.-H. M. Buschenfelde, and M. P. Dierich. 1976. Demonstration of binding sites for IgG Fc and the third complement component (C3) on isolated hepatocytes. J. Immunol. 117:639-645.

18. Dive, Ch., and J. F. Heremans. 1974. Nature and origin of the proteins of bile. I. A comparative analysis of serum and bile proteins in man. Eur. J. Clin. Invest. 4:235-239.

19. Dive, Ch., R. A. Nadalini, J.-P. Vaerman, and J. F. Heremans. 1974 Origin and nature of the proteins of bile. II. A comparative analysis of serum hepatic lymph and bile proteins in the dog. Eur. J. Clin. Invest. 4:241-246.

20. Dahlgren, U. I. H., J. Svanvik, and C. Svanborg Eden. 1986. Antibodies to Escherichia coli and anti-adhesive activity in paired serum, hepatic and gall bladder bile samples. Scand. J. Immunol. 24:251-260.

21. Wu, H.-Y., and M. W. Russell. 1992. Antibody-secreting cell responses in the mouse liver. Immunology. 77:443-448.

22. Hansen, P. G. C., E. J. Hennessy, H. Blake, R. L. Clancy, R. Kamath, C. Molenaar, A. W. Cripps, and G. D. F. Jackson. 1989. Appearance of IgG and IgA antibodies in human bile after tetanus toxoid immunization. Clin. Exp. Immunol. 77:215-220.

23. Carter, L., P. J. Barrington, and G. D. F. Jackson. 1989. Antibody responses in the liver and bile of rats injected with horse erythrocytes. Immunol. Cell Biol. 67:135-139.

24. Carter, L., P. J. Barrington, G. N. Cooper, and G. D. F. Jackson. 1987. Antibody synthesis in the rat liver: an association between antibody-forming cells in the liver and biliary antibodies following intravenous injection of horse erythrocytes. Int. Arch. Allergy Appl. Immunol. 82:153-158.

25. Hansen, P. G. C., and G. D. F. Jackson. 1990. The occurrence and sources of natural antibody in human bile and serum against the $\mathrm{O}$ antigens of two Escherichia coli serotypes. Scand. J. Immunol. 32:537-544.

26. Dvorak, J. A., A. W. Jones, and H. H. Kuhlman. 1961. Studies on the biology of Hymenolepis microstoma (Dejardin, 1845). J. Parasitol. 47:833-838.

27. Scott, A. J., and G. A. Khan. 1967. Origin of bacteria in bileduct bile. The Lancet. 2:790-792.

28. Richman, L. K., R. J. Klingenstein, J. A. Richman, W. Strober, and J. A. Berzofsky. 1979. The murine Kupffer cell. I. Characterization of the cell serving accessory function in antigen-specific T cell proliferation. J. Immunol. 123:26022609.

29. Rubinstein, D., A. K. Roska, and P. E. Lipsky. 1987. Antigen presentation by liver sinusoidal lining cells after antigen exposure in vivo. J. Immunol. 138:1377-1382.

30. Magilavy, D. E., F. W. Fitch, and T. F. Gajewski. 1989. Murine hepatic accessory cells support the proliferation of Th1 but not Th2 helper T lymphocyte clones. J. Exp. Med. 170:985-990.

31. Lautenschlager, I. 1984. Characteristics of the strongly Ia-positive cells in rat liver. Scand. J. Immunol. 20:333-338.

32. Goossens, P. L., H. Jouin, G. Marchal, and G. Milon. 1990. Isolation and flow cytometric analysis of the free lymphomyeloid cells present in murine liver. J. Immunol. Methods. 132:137-144.

33. Tan, B. D., and A. W. Jones. 1967. Autoelimination by means of X-rays: distinguishing the crowding factor from others in premunition caused by the mouse bile duct cestode, Hymenolepis microstoma. Exp. Parasitol. 20:147-155. 